Czytelnika RBL zainteresuje przede wszystkim tematyka biblijna obecna na tymże seminarium. W programie były przewidziane dwie grupy robocze (groupes de travail, workshops): 1 . ST i socjologia, 2. NT i socjologia. Ponieważ okazało się, że zbyt mało biblistów zglosiło swój udział w tym spotkaniu, dlatego połączone te dwie grupy w jedną: nauki biblijne a socjologia.

Wygłoszono następujące referaty $\mathrm{z}$ ciekawą i pouczającą dyskusją:

E. Kellenberger, szwajcarski proboszcz zajmujący się biblistyką, opracował ciekawy temat $\mathrm{z}$ bogatą literaturą: „Osadnictwo na wzgórzach izraelskich w okresie żelaza I".

C. Hardmeier, z Uniwersytetu w Greifswald, mówił „O literaturze socjologicznej na temat proroków przy końcu epoki królewskiej”.

J. Chmiel zaproponował mocno dyskutowany temat " "Socjofonia" na przykładzie święta Szawuot - Pentecostes".

I wreszcie Z. Sázava, z wydziału teologii husyckiej Uniwersytetu Karola w Pradze mówił o „Nowotestamentalnej eschatologii jako normie”.

Uroczo położone centrum konferencyjne Seeblick w Emmetten wpływało stymulująco na dyskusję nad referatami i choć nie było wielu uczestników, to jednak zwrócono uwagę na potrzebę uwzględniania aspektów socjologicznych przy interpretacji tekstów biblijnych. Warto przy okazji przypomnieć, że Dokument Papieskiej Komisji Biblijnej o interpretacji Pisma świętego $\mathbf{w}$ Kościele $\mathrm{z} 1993 \mathrm{r}$. podkreśla rolę socjologicznego podejścia (approche) do Biblii (por. I D 1). Jakkolwiek trzeba pamiętać o pewnym ryzyku, na jakie narażają się egzegeci, będący zwolennikami socjologicznego podejścia do Biblii, to jednak ten aspekt otwiera przed egzegezą szerokie perspektywy i przynosi wiele korzyści. Wykorzystanie modelów dostarczanych przez różne dyscypliny socjologiczne zapewnia egzegezie biblijnej i w ogóle interpretacji Biblii - cenną możliwość ciaggłego odnawiania się, pod warunkiem, że nie będzie się naginać tekstu biblijnego do stampowych modeli socjologicznych.

Mam wrażenie, że takie niestampowe modele socjologiczne $w$ odniesieniu do analizy tekstu Biblii zostały zaproponowane na międzynarodowym seminarium interdyscyplinarnym w pięknej scenerii pomiędzy szczytami Pilatus, Bürgenstock, Rigi, niedaleko przelęczy Gottharda, $400 \mathrm{~m}$ nad Jeziorem Czterech Kantonów, gdzie Szwajcarzy wspominają początki swego wolnego kraju.

Ks. JERZY CHMIEL

\title{
KOMUNIKAT TOWARZYSTWA BIBLIJNEGO W POLSCE
}

Dnia 26 marca 1996 r. odbyło się w siedzibie Towarzystwa Biblijnego w Warszawie posiedzenie Komitetu Krajowego Towarzystwa Biblijnego w Polsce (dalej KKTB), w skład którego wchodzą Kościoły:

Kościół Katolicki, Polski Autokefaliczny Kościół Prawosławny, Kościół Ewangelicko-Augsburski, Kościół Polskokatolicki, Kościół Starokatolicki Mariawitów, Kościół Ewangelicko-Reformowany, Kościół Ewange- 
licko-Metodystyczny, Kościół Adwentystów Dnia Siódmego, Kościół Chrześcijan Baptystów, Kościół Zielonoświątkowy i Społeczność Chrześcijańska.

Obradom przewodniczył Wiceprzewodniczący Komitetu Krajowego ks. Jerzy Banak (Kościół Katolicki).

Posiedzenie zaszczycili swą obecnością: J.Em. Metropolita Bazyli Doroszkiewicz Prawosławny Metropolita Warszawski i Całej Polski (Kościól Prawosławny - Patron Towarzystwa Biblijnego w Polsce) i członek honorowy Towarzystwa Biblijnego w Polsce J.E. Ks. Bp Zdzisław Tranda (Kościół Ewangelicko-Reformowany), który rozpoczął posiedzenie modlitwą i Słowem Bożym.

Śprawozdanie $\mathrm{z}$ działalności Towarzystwa Biblijnego za okres od 21 listopada 1995 do 26 marca 1996 roku przedstawila Dyrektor Generalny Towarzystwa Biblijnego w Polsce, Pani Barbara Enholc-Narzyńska. W swoim wystąpieniu zatytułowanym: „Pismo św. księgą wspólnoty” wskazała na trzyletni okres działalności Towarzystwa Biblijnego w nowej strukturze organizacyjnej. Zmiany te wzbogaciły naszą posługę biblijną i nadały jej nową jakość. Szczególnie jesteśmy Bogu wdzięczni za dar ekumenicznego braterstwa, w służbie Pismu św., które pozwoliło nam na podjęcie inicjatywy ekumenicznego wydania Pisma św. na Jubileusz chrześcijaństwa w roku 2000, łącznie ze wszystkimi Kościołami reprezentowanymi w KKTB. Widomym znakiem naszych wspólnych poczynań niech będzie wydany ostatnio, przez J.E. Ks. Bp. K. Romaniuka wspólnie z Towarzystwem Biblijnym w Polsce: „Czwarty Rozdział Ewangelii Łukasza, komentarz biblijny dla potrzeb ekumenicznych obchodów Jubileuszu 2000-lecia chrześcijaństwa".

Jezus Chrystus przemienia naszą codzienność i otwiera horyzonty nadziei. W ten sposób usiłujemy odpowiedzieć na wyzwania naszych czasów, świadomi, że bez Pisma św. nie można zrozumieć rzeczywistości ludzkiej, potrzebującej zbawienia. Dlatego tak ważne było dla nas w ciągu minionych trzech lat doświadczenie wspólnoty ekumenicznej, dobrej współpracy, co pozwoliło nam na stałe wprowadzić Ekumeniczne Niedziele, Soboty i Dni Biblijne, święcone wspólnie ze wszystkimi Kościołami w maju każdego roku w całej Polsce. Przyjęto też program Ekumenicznych Dni Biblijnych dla Warszawy, obchodzącej 400-lecie swej stołeczności w roku bieżącym.

W związku z upływem kadencji wybrano nowe władze Towarzystwa Biblijnego. Przewodniczącym KKTB został ponownie Ks. prof. dr Witold Benedyktowicz (Kościół Ewangelicko-Metodystyczny), Wiceprzewodniczącym Ks. mgr Jerzy Banak (Kościól Katolicki), Skarbnikiem Ks. prot. Mikołaj Lenczewski (Kościól Prawosławny). Wybrano Komisję Rewizyjną w składzie: Ks. prof. dr hab. Zachariasz Łyko - Przewodniczący, Ks. Prezbiter Henryk Sacewicz i Ks. Witold Szymański - członkowie.

Do składu Komitetu przyjęto trzech nowych członków: Ks. Henryka Sacewicza, reprezentującego Kościół Zborów Chrystusowych, Ks. Rektora Gustawa Cieślara z Kościoła Chrześcijan Baptystów, oraz Ks. mgr. Zbigniewa Kamińskiego z Kościoła Ewangelicko-Metodystycznego.

Gośćmi zebrania byli biskupi ze Starokatolickiego Kościoła Mariawitów: J.E. Ks. Bp Antoni Nowak i J.E. Ks. Bp Ludwik Jabłoński.

W imieniu przedstawicieli Kościołów członków KKTB życzenia obfitego Bożego błogosławieństwa Wiceprzewodniczącemu KKTB ks. mgr. Jerzemu Banakowi z okazji Jego pięćdziesiątych urodzin, serdecznego oddania dla sprawy ekumenizmu i Pisma św. w naszym kraju złożyli: J.Em. Metropolita Bazyli Doroszkiewicz Prawosławny Metropolita Warszawski i Całej Pol- 
ski (Kościół Prawosławny), J.E. Ks. Bp Zdzisław Tranda (Kościół Ewangelicko-Reformowany) i Dyrektor Generalny Towarzystwa Biblijnego w Polsce Pani Barbara Enholc-Narzyńska (Towarzystwo Biblijne w Polsce). Zebranie KKTB zakończono modlitwą i błogosławienstwem.

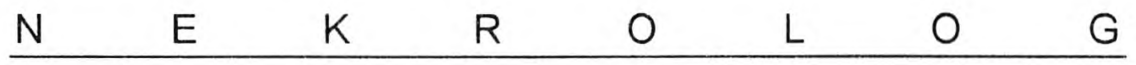

\section{Ks. Jerzy Chmiel}

\section{ŚP. KS. FRANCESCO VATTIONI (1922-1995)}

Biblista i orientalista włoski, ks. prałat Francesco Vattioni urodził się 3.II 1922 r. w miejscowości Orzinuovi, koło Bresci. Szkołę podstawową, gimnazjum i liceum oraz studia teologiczne $\mathbf{w}$ diecezjalnym seminarium duchownym odbył w Bresci, pięknym mieście w Lombardii, u stóp Alp Bergamskich, starożytnym mieście Brixia, założonym już $w$ VI wieku przed Chr. przez Gallów. Wyświęcony na kapłana 17.III 1945 r., został posłany na studia do Rzymu, gdzie w latach 1946-1949 uzyskał na Papieskim Ateneum Angelicum (dziś uniwersytecie) licencjat teologii. W tym też czasie studiowal jako hospes na wydziale orientalistycznym Papieskiego Instytutu Biblijnego (Biblicum), by następnie w latach 1949-1952 zdobyć tamże licencjat nauk biblijnych.

Od 1955 r. zacząl pisywać do czasopism naukowych. W latach 19581960 był redaktorem „Rivista Biblica” i pracował przy tłumaczeniu Starego Testamentu dla Sacra Bibbia w wyd. Mariettiego. W latach 1969-1971 otrzymał zlecenie pracy przy rewizji tekstu oficjalnego przekładu biblijnego Konferencji Episkopatu Włoch. Od r. 1968 pracował przy poprawie tekstu Wulgaty w ramach Papieskiej Komisji dla Neo-Wulgaty. W r. 1974 kierował edycją włoskiej wersji Biblii Jerozolimskiej dla Edizioni Dehoniane w Bolonii i wydawnictwa Borla.

Brał udział w naukowych podróżach na Bliski Wschód, zajmując się badaniami epigraficznymi $\mathrm{z}$ dziedziny semitystyki, co było wręcz jego naukowa pasją.

W r. 1967 został prywatnym docentem (libera docenza) filologii biblijnej i przez 5 lat prowadził lektoraty języka hebrajskiego, aramejskiego $i$ greki biblijnej w wydziale humanistycznym Uniwersytetu Rzymskiego. Od r. 1977 do swojej emerytury w r. 1992 pracowal w Instytucie Orientalistycznym w Neapolu zrazu jako profesor zaproszony (incaricato), a na- 